M. М. Алексеева (Москва, Россия)

\title{
Лемковский журнал «Ватра» как источник изучения социолингвистической ситуации и диалектных особенностей современных лемковских говоров
}

Лемковский идиом представляет интерес не только для диалектологов, но и для социолингвистов как недавний пример диалекта, получившего (по крайней мере отчасти) статус отдельного языка.

Традиционно лемковский диалект относится к югозападному наречию украинского языка и считается самым западным украинским диалектом. Его носители, лемки, изначально проживали на юго-востоке Польши в горных районах на границе со Словакией (так называемая Лемковщина). В 1945-1947 гг. в результате принудительных переселений лемки оказались рассредоточены по различным областям Польши и Украины, что имело серьезнейшие языковые последствия (Алексеева 2012; Алексеева 2015).

Среди лемков в Польше наблюдается так называемый «этнический дуализм» (Michna 1995): часть из них считает себя частью украинской нации, а часть — отдельным народом или одной из ветвей отдельного русинского народа. Этническая идентификация влияет и на отношение к своему языку. Так, лемки-автономисты в Польше добились признания своего идиома отдельным восточнославянским языком, что вызывает резкое отторжение у приверженцев проукраинской ориентации.

Важной площадкой для дискуссий являются периодические издания, выпускаемые лемковскими общественными организациями. Языковая политика редакции того или иного издания во многом отражает взгляды стоящей за ним общественной организации. 
Характерным примером служит журнал «Ватра» - печатный орган Объединения лемков в Польше (Zjednoczenie Lemków w Polsce), отстаивающего принадлежность лемков к украинскому народу и считающего лемковский идиом диалектом украинского языка.

Ежеквартальный журнал «Ватра» выходит в Польше с 1992 г., на данный момент издано 114 номеров. В журнале публикуются хроники событий в жизни лемковского сообщества Польши и Украины, материалы по истории лемков, литературные произведения, воспоминания очевидцев переселений, фольклорные материалы. Важное место занимают статьи, посвященные статусу лемковского идиома и лемковского сообщества.

Значительная часть материалов публикуется на украинском литературном языке, однако в каждом номере обязательно имеются публикации на лемковском. Кроме того, встречаются тексты на украинском языке, написанные потомками лемков-эмигрантов из англоязычных стран, в частности Австралии. Согласно принятым правилам, в них сохраняется авторская орфография, что позволяет проследить некоторые особенности речи украинцев Австралии (например, в тексте, опубликованном в № 1 «Ватры» за 2009 год, отмечены случаи отсутствия окончания предложного падежа у топонимов на -н: народилася в Мельберн, не живу у Брізбан, ср. в том же тексте в Сіднею, на північ від Брізбану род. пад.).

В отличие от лемков-автономистов, добивавшихся кодификкации лемковского языка на основе говоров центральной Лемковщины, лемки-украинцы негативно относятся к идее создания единого лемковского стандарта. Следовательно, в публикуемых лемковских текстах целенаправленно сохраняется авторская орфография. Редакция пишет: «Ми вже не раз пояснювали, що наш квартальник друкуємо в більшості лемківською говіркою <..> жодна говірка не може бути 
літературною мовою народу, а коли стане мовою, не буде вже говіркою» («Ватра», 2011, № 2, с. 12).

Редакция лишь изредка позволяла себе правку оригинальных материалов, что не всегда вызывало одобрение авторов и даже приводило к курьезным ситуациям. Так, в одном случае редакция решила заменить в присланном материале букву «и» на букву «ы», которая служит для передачи специфического лемковского звука [ы] верхнего (верхне-среднего) подъема заднего (средне-заднего) ряда. Это своего рода фонетическая «визитная карточка» лемковских говоров, хотя еще 3. Штибер писал о тенденции к более переднему произношению * $y$ (Stieber 1982: 33). По словам редакции, эта буква в журнале используется только в рубрике «Бесіда русинів Лемківщини», в которой публикуются воспоминания лемков. Однако автор исправленного материала в ответном письме потребовал убрать изменения, поскольку в говоре его родного села Высова звук [ы] отсутствовал, что резко отличало говор Высовы от говоров окружающих сел и что подтверждают данные атласа лемковских говоров (Stieber 1956).

Не все читатели журнала согласны с позицией редакции. Некоторые считают ошибочным и нецелесообразным использование диалекта в печати: «Я сам не пишу діалектом, бо вважаю, що для висловлення своєї думки на профресійні теми треба вживати нормалізовану, літературну мову; на щастя, таку мову вже маємо» («Ватра», 2005, № 4, с. 9).

Отметим, что литературный украинский язык публикаций журнала несет следы влияния польского языка. Об этом свидетельствуют, к примеру, случаи нетипичного управления (над морьол 'на море' - ср. укр. лит. на лорі, пол. nad morzem; прошу о контакт 'пожалуйста, свяжитесь со мной' - ср. укр. лит. прошу + вин. пад. без предлога, пол. proszę o kontakt) или специфическое написание имен собственных, несвойственное литературному стандарту (Осьвєниіл - укр. лит. Освенцил). 
Лемковский идиом на протяжении всей своей истории испытывал значительное влияние польского языка (Rieger 1995: 18-20), а в результате переселений контакты с польским языком интенсифицировались. Кроме того, на сегодняшний день практически все носители лемковского двуязычны, причем для молодого поколения польский язык зачастую является примарным, а знание лемковского чаще остаточное или пассивное. Обилие полонизмов на страницах «Ватры» (как адаптированных, так и неадаптированных) указывает на сильнейшее влияние польского языка на современную лемковскую лексику (колірка 'мобильный теледон', ср. пол. komórka; теле-диск 'видеоклип', ср. пол. teledysk; варштати 'мастер-классы', ср. пол. warsztaty; uертиббікат 'сертификат', ср. пол. certyfikat; викалачка 'зубочистка', ср. пол. wykataczka). Можно встретить объявления с частично продублированной информацией на польском и украинском и даже переключением кодов в рамках одного предложения: «Щиро запрашаме на: Małankę Маланку 2009/2010, котра одбудеся 13.01.2010 в: Ośrodku Wypoczynkowym "Wapienne” w Wapiennym» («Baтра», 2010, № 1, с. 26).

Отдельного упоминания заслуживают рубрики «Дитяча сторінка» и «Молодіжна сторінка». В них преобладают публикации на лемковском, поскольку среди прочего преследуются образовательные цели: ближе познакомить молодежь с традициями предков. Однако для лемковских слов, которые могут вызвать затруднение у современной молодежи, в скобках приводится польское соответствие, причем это могут быть как явные архаизмы, так и - что показательно - нейтральная бытовая лексика (зрізуванеи (szczypiorek) 'зеленый лук' рідковия (rzodkiewka) 'редиска', виразка (wrzody) жолудка 'язва желудка').

О выходе из употребления многих специфических лемковских лексем свидетельствует и тот фракт, что к текстам, 
опубликованным в рубрике «Бесіда русинів Лемківщини», зачастую прилагается объяснение малопонятных слов на украинском языке, и это могут быть как обозначения утративших актуальность реалий, так и базовая лексика (гнеска - сьогодні 'сегодня', тыл барже - тил більше 'тем более').

Помимо косвенных указаний на особенности социолингвистической ситуации в журнале публикуются материалы, напрямую ей посвященные. В частности, обсуждение двуязычных информационных указателей на польском и лемковском в селах Лемковщины («Ватра», 2009, № 1), отражающее непростые моменты во взаимоотношениях польского и лемковского населения на этих землях.

\section{Литература}

Алексеева 2012 - Алексеева M. M. Языковой выбор у лемков-переселенцев на Украине // Исследования по славянской диалектологии. [Вып.] 15: Особенности сосуществования диалектной и литературной форм языка в славяноязычной среде / [отв. ред. вып. Л. Э. Калнынь]. М.: Ин-т славяноведения РАН, 2012. С. 72-82.

Алексеева 2015 - Алексеева M. M. Лемки-переселенцы в Польше: этническое самосознание и языковая ориентация // Актуальные этноязыковые и этнокультурные проблемы современности / [отв. ред. Г. П. Нещименко]. Кн. 2. М.: Рукописные памятники Древней Руси, 2015. (Studia philologica). С. 59-72.

Michna 1995 - Michna E. Łemkowie. Grupa etniczna czy naród? Kraków: Nomos, 1995. (Religiologica Juventa).

Rieger 1995 - Rieger J. Słownictwo i nazewnictwo łemkowskie. Warszawa: Wydawnictwo naukowe «Semper», 1995.

Stieber 1956 - Stieber Z. Atlas językowy dawnej Łemkowszczyzny / Łódzkie Towarzystwo Naukowe. Zesz. 1-8. Łódź: Zakład im. Ossolińskich we Wrocławiu, 1956-1964.

Stieber 1982 - Stieber Z. Dialekt Łemków: fonetyka i fonologia / Polska Akademia Nauk, Komitet Jezykoznawstwa; komitet redakcyiny: K. Polański (red. nacz.) et al. Wrocław; Warszawa; Kraków; Gdańsk; Łódź: Zakład Narodowy im. Ossolinskich: Wydawnictwo Polskiej Akademii Nauk, 1982. (Prace językoznawcze; 97). 


\section{"Watra" Magazine as a Source of Information about the Sociolinguistic Situation and Specific Features of Modern Lemko Dialects}

"Watra" magazine is published by the Union of Lemkos in Poland. It represents the views of those Lemkos who consider themselves part of the Ukrainian nation and believe their language is a Ukrainian dialect as opposed to those Lemkos who claim to constitute a separate nation with a separate Lemko language. According to the editorial policy the magazine publishes texts in both standard Ukrainian and different versions of the Lemko dialect which allows to study the ongoing processes in the Lemko vernacular. 